\title{
Effect of Number Limit of Advisors' Graduate Students on Students' Learning Attitude toward Thesis Writing
}

\author{
Hsiao-Chuan Hsiang Peng* \\ Department of Education \\ National University of Tainan \\ Tainan, Taiwan \\ Email: m10203019@stumail.nutn.edu.tw \\ *Corresponding author
}

\author{
Shueh-Chin Ting \\ Department of Education \\ National University of Tainan \\ Tainan, Taiwan \\ Email: tingsc@ms49.hinet.net
}

\begin{abstract}
In graduate students' study and thesis writing, advisors are significantly influential. Therefore, relationship between advisors and students is extremely important. With positive relationship, advisors will advise students with efforts and have positive daily interaction with students. According to the researcher's observation, in almost all graduate schools in Taiwan, there is the number limit of advisors' students. Hence, many graduate students cannot find the favorite advisors. Does the limit restrict advisors' receiving of students or graduate students' selection of advisors? How do graduate students feel when they cannot find the favorite advisors? Will it negatively influence their learning attitude toward the following thesis writing? What are the reasons? These are the focuses of this study. From perspectives of graduate students, we intend to explore number limit of advisors' students.
\end{abstract}

To collect data, this study plans to conduct interviews on graduate students who currently study in master and doctoral programs in Taiwan, who have advisors that are not their priority and who are unsatisfied. This study selects subjects by purposive sampling, in consideration of average distribution of gender, age and college. The outline of self-designed semistructured interview is the tool of interview. One-on-one interview is conducted on 20 subjects.

By interview with graduate students, this study will recognize graduate students' views toward number limit of advisors' students and the effect on their learning attitude toward thesis writing. When number limit will be the obstacle and problem for students' selection of advisors and influence students' learning attitude toward thesis writing, the departments should thus consider the problems of graduate students' rights and system. Thus, result of this study will be the reflection on regulation of number limit of advisors' students.

Keywords- advisors; graduate students; number limit of students; learning attitude

\section{INTRODUCTION}

In Taiwan, since the liberation of higher education in 2000, the number of graduate schools has been rapidly growing [1]. In 2012, there were about 183,000 graduate students. In average, among 6.8 students with educational level above university, one is a graduate student [2]. Regarding development and distribution of higher education, Hsu [3] suggested that because of the effect of fewer children, higher education will encounter shortage of students recruited, high acceptance rate and increased number of vacancy. Hence, gap between numbers of teachers and students in graduate schools will increase. In the past, since there were more candidates and acceptance rate was low, students worried that they could not find the advisors. Thus, before publication of the list of candidates in graduate schools, many active students fought for the waiting list of popular advisors with their school reports. However, nowadays, vacant positions increase, and democratic consciousness rises; hence, students in graduate schools are more independent and rational. In recent years, Ministry of Education guides students' multiple intellectual development, adaptive learning and cultivates diverse excellent talents. The educational policies focus on students' learning rights and options and it tries to allow students to have more options in schools [4].

With the concern of students' options, since there are more advisors and fewer students and in order to avoid the wrong decision to choose the advisors or students, the graduate schools extend the time limit (such as three months or before the end of the second semester of the first year) for graduate students to find their advisors. Thus, graduate students have half or one year to select the appropriate advisors for their theses. However, the researcher finds that in current selection system, advisors have number limit when receiving graduate students. Is number limit of students the main factor of advisors' and graduate students' different opinions in process of thesis writing? With the regulation of number limit of students, will students not be able to find their favorite advisors? What is the effect on learning attitude? Thus, the researcher suggests that it is necessary to explore current practice of number limit of students when students select their advisors.

The research purposes are as follows:

1) to find graduate students' main concerns when selecting advisors;

2) to find the effect of number limit of students on graduate students' selection of advisors; 
3) to find effect of advisors on students' learning attitude toward thesis writing when graduate students do not find their favorite advisors

Most of past studies explored advisors' instruction and apprenticeship between advisors and graduate students [5]. In foreign research on related issue, only Liang, Joy, Bilimoria \& Perry, [6] studied advisors of doctoral students by model of universities in the U.S. However, they did not mention number limit of students. Liao [7] suggested that although schools are non-profit business, the purpose of education and research is to recognize all educational factors through research process and outcome in order to solve educational problems. Therefore, based on three motives of this study, the researcher indicates that it is necessary to have general discussion on correlation between number limit of students and students' learning attitude toward thesis writing. If number limit of students negatively influences students' selection and their learning effectiveness, future educational policy can be re-adjusted. Finding of the research aims to serve as one of important references to assess educational reform.

\section{RESEARCH METHOD}

This study aims to explore effect of advisors' number limit of students on students' learning attitude toward thesis writing and analyze the causes through practice. Since there was no related research in the past, this study adopts qualitative research method in order to explore the topic from graduate students' perspective.

\section{RESUlTS AND DISCUSSION}

\section{A. Graduate students' main concerns when selecting advisors}

When students are in graduate schools, the professors' "academic reputation" and "future career development" are critical concerns of selection. Although currently, there are evaluations on university professors' academic reputation [810], for graduate students, it is seemingly limited to select advisors simply by academic reputation.

Besides the assessment on academic reputation, research of Liang et al., [6] suggested that before graduation, graduate students must accomplish two important parts: credits of courses and theses. In graduate schools, graduate students are in small groups in class. They select the courses by personal intention. They can have personal options in professional courses. Hence, students can select the advisors with capacity to guide students' study, growth and graduation by taking the courses. However, the selection is two-way process. When graduate students select advisors, the advisors will have their principle and assessment on graduate students. According to Figure I, students will try to find if the advisors' research is supported by National Science Council or industry-school cooperation projects and recognize their research fields, personalities, work attitude, senior students' graduation from laboratory and the graduates' employment and career. Advisors evaluate students' educational level (schools of graduation and grades) /experience, personality and competence to undertake future research. The mutual evaluation is mainly influenced by professors' gender, research field, academic positions and students' educational level and experience. Hence, time limit and the regulations in different departments will influence the final selection.

According to the interview, in the trend of internationalization, regarding the selection of advisors, students prefer the professors with higher international academic positions and those with special school administration positions such as chairmen of department or deans. For them, professors' positions will influence the sources of students' funds. In addition, professors' capacity to solve graduate students' problems is one of the factors of students' selection of advisors since the professors are the important others to provide the solutions. However, when the professors' research development is not as students' expectation, it influences students' selection. Moreover, the number of seniors of doctoral degree is also one of the concerns for students since the doctoral seniors can substitute the advisors to assist with the juniors' academic and research obstacles in the situations that advisors are too busy or the classmates cannot discuss with each other due to different levels.

\section{B. Effect of advisors' number limit of students on graduate students' selection of advisors}

When advisors undertake students, there is number limit. How many students can advisors receive? Although there are different regulations in different schools, the number is limited. It is based on percentages of teachers and students. In other words, each qualified professor can instruct the students. When analyzing operational strategy of higher education, Tang [11] suggested that if schools apply the same education operational strategy on students with different needs, the students will not be satisfied. Teachers' number limit of students will certainly influence students' selection. The regulation is significant restriction for graduate students with great intention of research.

Advisors' students instructed are limited by schools. Although the time limit of selection is one year, students might make impulsive or even wrong decision. Thus, students might not find their favorite advisors. Therefore, is the number limit of students a fair system for students? Are there inappropriate results? Will students disagree with it? Will students leave the schools since they cannot find the favorite advisors? Should we respect students' intention? Liu [12] suggested that students are consumers in higher education market. Students' selection is one of consumers' purchase behaviors. Higher education should be the servers and provide learners with high-quality service instead of restricting students' options. Hence, how will advisors' number limit of students influence graduate students? The researcher tries to respond to this question.

\section{Effect of number limit of students on graduate students' learning attitude toward thesis writing}

Interactive model between graduate students and advisors is two-way and it is based on traditional apprenticeship. The model is based on the accomplishment of thesis for cultivation and training of research capacity [13]. Thus, after students pass the examination of graduate schools, they start learning the course of thesis writing [14]. In graduate schools, professors are divided into different groups according to personal research fields [15]. Using social science as an example, the teachers can be classified into the ones of qualitative and quantitative 
research. When students do not have sufficient mathematical and scientific capacity, they will try to consult the professors of qualitative research. However, with number limit of students, they are forced to be instructed by advisors of quantitative research. Will students be as satisfied with life in graduate school as the selection of advisor of qualitative research?

Graduate students are in small groups in class of graduate schools. They select the courses by their personal intention and they can select professional courses independently. By the courses, students can easily understand the professors' research directions and have positive interaction with them [16]. Thus, after the students spend time finding the favorite professors by taking the courses and are forced to give up their favorite due to time limit, will they be unsatisfied in learning attitude? Astin [17] and González [18] suggested that when students are more satisfied with personal achievement and learning experience, they will spend more time and efforts in learning. Their learning intention will be higher. Therefore, in order to enhance students' development, educational environment should first assess and recognize the students' feelings. When students recognize the balance between support and challenge in the environment, they will have positive development [19]. Ting \& Yang [20] suggested that when graduate students write the theses, the advisors instruct and help graduate students to expand their thinking and ideas. They guide the graduate students to discover and solve the problems in the writing. Hence, graduate students must support advisors' instruction in order to accomplish their theses in long term. However, if the advisors are not their favorite, how will they feel in the process of thesis writing?

Interaction between graduate students and advisors in thesis writing includes instruction in class, instruction of graduate students' theses, meetings \& reports and meetings with students [21]. Thus, in graduate students' thesis writing, advisors usually instruct them by two methods: group discussion and personal meeting. By group discussion, students can learn the peers' research content and discuss the solution to the problems [22, 23]. Personal meeting is the face-to-face and individual instruction [24]. The two methods aim to train graduate students' expression capacity. Therefore, graduate students' learning life is associated with advisors. Graduate students should accomplish thesis writing by continuous communication with advisors. Thus, importance of advisors is that they spend significant time and efforts on graduate students in thesis writing and when students encounter the difficulty in writing, they support and encourage the students [24-26] and provide graduate students with professional knowledge and instruct them the writing techniques. They are extremely important. How can graduate students be forced to give up their favorite advisors due to number limit of students? "Graduation" is all graduate students' expectation. Research is the "literacy" required for graduate students. When graduate students cannot find their favorite advisors, will their research life and graduation years be influenced? There are still no literatures on effect of advisors' number limit of students on graduate students. By interviewing graduate students, the researcher learns graduate students' feelings toward number limit of students. The finding of this study aims to serve as one of important references to assess educational reform.
In fact, at the beginning, all students are restricted by number limit, including project students, pre-graduate students, screening test students, examination students and even the first and second stages of students on waiting list (they are on waiting list when some students are not registered after the beginning of semester). It is the reality of graduate schools nowadays. Due to the trend of low birth rate, the situation may not be more serious, but it is likely to continue. In graduate schools, many professors only receive specific students or the directly promoted ones in schools. When graduate students cannot select their favorite professors in the study of graduate schools, most of them feel disappointed or helpless. Noticeably, the professors' field should match the graduate students' intention; otherwise, the students will not demonstrate their capacity or have acquisition when they cannot match their interest with learning.

\section{CONCLUSION}

When selecting advisors, the graduate students wish that the professors would not have number limit and they can discuss with students before deciding the receiving. They can also flexibly add two or three places. Thus, when other professors' research directions do not match the students' expectation, the proper professors can have the flexibility to receive them. The departments can invite the students to provide the ranking of their favorite professors and professors select the students by some measures. Hence, they match each other, and graduate students and advisors could have better interaction in the following two years. The method is more appropriate than "first come, first received".

\section{REFERENCES}

[1] Department of Statistics, Ministry of Education, 2005, http://www.edu.tw/EDU_WEB/EDU_MGT/STATISTICS/EDU7220001 /service/statis.htm?TYPE=1\&UNITID=96\&CATEGORYID=0\&FILEI $\mathrm{D}=121255$.

[2] Department of Statistics, Ministry of Education, 2013, http://www.edu.tw/pages/detail.aspx?Node=3378\&Page=14083\&Index= 5\&WID=31d75a44-efff-4c44-a075-15a9eb7aecdf

[3] M.J. Hsu, http:// www.npf.org.tw/PUBLICATION/EC/095/EC-R-095003.htm.

[4] S.K. Tsai, A study of Influencing Factors to Attending Community High School by Students- A Perspective of Theory of Planned Behavior, Institute of Public Affairs Management, National Sun Yat-Sen University Master Thesis, 2013.

[5] M. Martinsuo, and V. Turkulainen, Personal commitment, support and progress in doctoral studies, Studies in Higher Education, 36, no.1: 103120, 2011.

[6] X. F. Liang, S. Joy, D. Bilimoria, and S. Perry, Choosing doctoral advisors/advisees: Empirical model from an American University, 2011

[7] J.S. Liao, Relationship between Learning Motivation and Satification Degree for Master's Degree Class, National Pingtung College of Education Master Thesis, 2004.

[8] S.W. Marion, Variables influencing graduate business student's college selections. College and University, 68(1), 38-46, 1992.

[9] R.L. Coccari, and R.G. Javalgi, Analysis of students' needs in selecting a college or university in a changing environment. Journal of Marketing for Higher Education, 6(2), 27-39, 1995.

[10] C.L. Comm, and D.G. Labay, Reposition colleges using changing student quality perceptions: An exploratory analysis. Journal of Marketing for Higher Education, 7(4), 21-34, 1996.

[11] Y. Tang, The Construction of the Development Strategies of Higher Education: In Case of Internal Quality Assurance and External 
Benchmarking System, Educational Research \& Information, 10(5), 127, 2002.

[12] J.H. Liu, Exploring University Students'Intentions about Choosing the Research Institute of Their Original School with Theory of Planned Behavior, National University of Tainan Master Thesis, 2010.

[13] S. Acker, T. Hill, and E. Black, Thesis supervision in the social science: Managed or negotiated? Higher Education, 28, 483-498, 1994.

[14] Y.L. Lin, A Study of Taiwanese Graduate Student's School Choice and Studing Factors, National Taichung University of Education Master Thesis, 2014.

[15] H.C. Chiang, A Case Study of School Improvement Propelled by Teacher Evaluation for Professional Development, National Taiwan Normal University Master Thesis, 2008.

[16] J.A. Dawson, Effects of instructor-leader behavior on student performance, Journal of Applied Psychology, 56,369-376, 1972.

[17] A.W. Astin, What matters in college? Four critical years revisited. San Francisco: Jossey Bass, 1993.

[18] P.A. González-Moreno, Student motivation in graduate music programs: An examination of personal and environmental factors. Music Education Research, 14(1), 79-102, 2012.
[19] H.L. Cheng, The Effects of the Thematic Approach Integrating Curriculum on Music Learning Attitude and Achievement by Junior High School Students, Normal University Master Thesis, 2004.

[20] S.C. Ting, C.C. Yang, The Types and Effects of Relational Bonds between Advisor and Graduate Student, Journal of Educational Research and Development, 7(4), 131-164, 2011.

[21] T.C.Chou, S.C. Wu, A Study for the Model of Graduate Students' Capability Development in Taiwan, Ming Chuan Journal of Education, 3, 38-61, 2011.

[22] Y.C. Lin, The Effects of the incorporating picture books into Limited Writing Instruction of Elementary Students with Learning Disability, National University of Tainan Master Thesis, 2008.

[23] R.J. Wu, The Effect of Mind Mapping Implemented in Junior High School Students' Narrative Writing, National Ocean University master Thesis, 2011.

[24] Y.L. Liu, Effects of Mentorship on the Organizational Socialization, National Central University Master Thesis,2006.

[25] T.Y. Lin, A study at the factors of psychological distance between postgraduate students and supervisors, National University of Tainan, 2007.

[26] M.C. Tsai, The study of Advisers' Leadership Styles and Thesis Mentoring Relationships- An Example of Business Graduate School in Taiwan, Chang Jung Christian University Master Thesis, 2008.

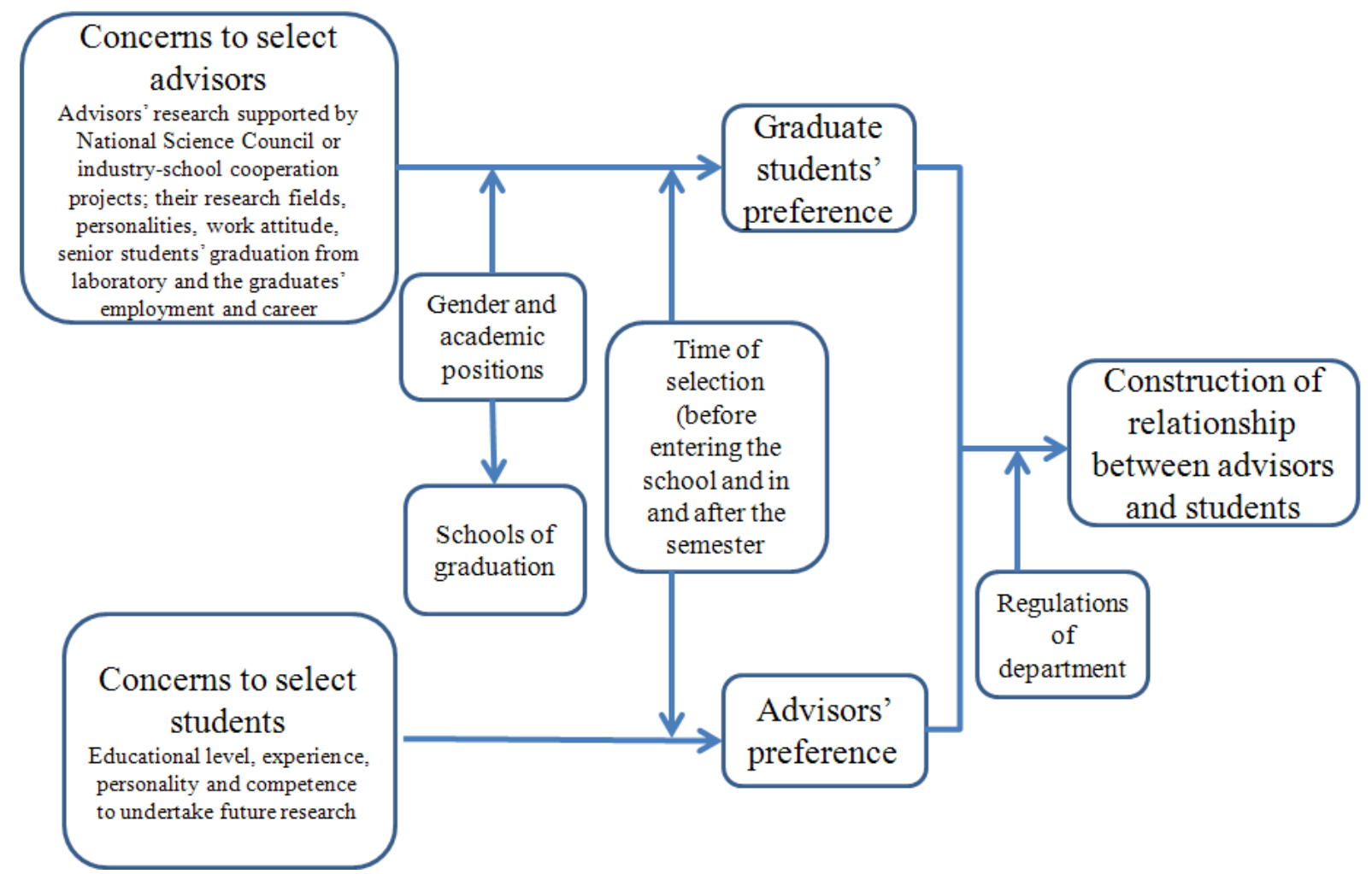

FIGURE I.

THE SELECTION PROCESS DURING THE CONSTRICTION OF RELATIONSHIP BETWEEN ADVISORS AND STUDENTS 